\title{
RELATIONSHIPS AMONG READING ANXIETY, READING SELF-EFFICACY, AND READING COMPETENCY IN THE VOCATIONAL HIGH SCHOOL IN SINGARAJA
}

\author{
Ni Luh Putu Devi Trisnayanti \\ English Language Education, Universitas Pendidikan Ganesha \\ e-mail: devitrisna171297@gmail.com \\ Dewa Ayu Eka Agustini \\ English Language Education, Universitas Pendidikan Ganesha \\ e-mail: eka.agustini@undiksha.ac.id \\ Dewa Komang Tantra \\ English Language Education, Universitas Pendidikan Ganesha \\ e-mail: komang.tantra@undiksha.ac.id
}

\begin{abstract}
The general objective pursued is to describe and to relate the students' reading anxiety, reading self-efficacy to their reading competency in the Vocational High School in Singaraja. The design applied is a quantitative research. There were 90 students recruited using cluster quota sampling. The data were gathered using scales and reading test. The obtained data were analyzed in two phases: descriptively and inferentially. Whereas inferentially, the data were analyzed using pair-wise correlation and multiple correlation technique. The findings show that: 1) the students' reading anxiety is at high level while reading self-efficacy and reading competency are at the low levels; 2) the relations pairwisely are negative and positive significantly correlated; ard 3) the simultaneous or multiple relationships of the reading anxiety and reading self-efficacy to the students' reading competency is proven to be significant $\left(R_{y x_{1} x_{2}}=0.81 ; \alpha=0.01\right)$.
\end{abstract}

Key Word: Multiple Correlation, Reading Anxiety, Reading Competency, Reading Self-Efficacy

\section{INTRODUCTION}

Reading is important in processing information in the current era. By reading, someone can get information consists of ideas, inspiration, and knowledges (Latifa \& Manan, 2018). Reading is not just getting the desired information but how someone can understand the contents of the information (Bahmani \& Farvadin, 2017; Latifa \& Manan, 2018). Since 2013, the so-called 2013 Curriculum has been implemented in Indonesia (Kementerian Pendidikan dan Kebudayaan, 2013). This curriculum is designed with a scientific approach. This is especially meant to replace the communicative approach in the teaching of English as a foreign language (TEFL). In general, the 2013 Curriculum is meant to improve the educational quality in Indonesia, including reading literacy.

In 2013 Curriculum, there is reading competency (Kurikulum 2013, 2018). Reading competency is a set of attitudes, knowledge, and skills in reading (Ikhwan, 2018). For students, reading is an important part to help in processing knowledge, idea creation, making decisions, and making solutions in the classroom (Satthapong, 2018). However, many students were not able in reading. Previous researcher showed that Indonesian students as EFL students failed the reading assessment compared to students in other 
countries (PISA, 2012, 2015, 2018). Based on the research, students were weak in obtaining information, interpreting text, and reflecting the text that was higher-order thinking level (Nugrahanto \& Zuchdi, 2019).

Many EFL students possessed deficiencies in reading. Data have shown clearly, the students' reading scores were declining over the years since 2012 to 2018 . When compared to other countries, Indonesia positioned lowest in the rank when they joined the Program for International Students Assessment (PISA) in three consecutive years, they are, 2012, 2015, and 2018.

In 2012, there were 65 countries including Indonesia participated in PISA (PISA, 2012). As reported in PISA, the Indonesian students' reading scores showed deficiencies. The students' reading scores, when compared to other countries, were ranked on 64 out of 65 countries (PISA, 2012). Moreover, their reading mean score was equal to 396 out a total score of 1000. The PISA's reading performance proofed that the scientific approach was not a better approach than the communicative approach. Simply concluded, the observation - question - exploration - association - and communication reading approach was not effective as yet for the students' in understanding high-order items (items beyond cognitive level 1,2 and 3; affective level 1 and 2; psychomotor level 1 and 2). They were not prepared to cope with high order thinking items.

In 2015, there were 70 countries participated in PISA (PISA, 2015). As reported in PISA, the Indonesian students' reading scores still showed deficiencies. The students' reading scores, when compared to other countries, were ranked on 62 out of 70 countries (PISA, 2015). Moreover, their reading mean score is 397 out a total score of 1000. The PISA's result proofed that the scientific approach was not a better approach than the communicative approach despite it has been deployed for three years. Simply concluded, the scientific reading approach was not effective as yet for the students' in understanding high-order items.

In 2018, there were 78 countries participated in PISA (PISA, 2018). As reported in PISA, the Indonesian students' reading scores still showed deficiencies. The students' reading scores, when compared to other countries, were ranked on 73 out of 78 countries (PISA, 2018). Moreover, their reading mean score dropped to 371 despite the new curriculum has been deployed for five years. The PISA's result proofed that the scientific approach was really a failure in developing the students' reading competency, especially in finishing up high-order items.

Other variables suspected to relate to reading competency are reading anxiety and reading self-efficacy (Habibian, Roslan, Idris, \& Othman, 2015). Predictor variables (reading anxiety and reading self-efficacy) which are estimated to be related to the improvement of children's critical thinking skills can be started from reducing children's worry about text in English relating to text descriptions about people, animals, places, objects and recount texts about experiences /events of someone who happened in the past. By reducing the anxiety of students will be able to increase confidence in the ability to understand both types of text, especially related to main ideas, specific ideas, word meaning, and textual references. Both predictor variables (reading anxiety and reading self-efficacy) are closely related to the competency students in reading (reading competency) or criterion variable.

The theory of "Personality Factors" by Douglas Brown in his book the title is Principles of Language Learning and Teaching (2007) explain that anxiety have relationship with self-efficacy, and competency. Anxiety has negative relationship with self-efficacy and competency because anxiety give negative effect for students in language learning process such as perfectionism, suggesting about high standard in learning which causes increased anxiety (Brown, 2007). 
The participants of this research are grade $\mathrm{X}$. The grade $\mathrm{X}$ students has a relationship with the age of participants who took the PISA Assessment. Reading competency in PISA uses higher-order-items. Competency in the 2013 curriculum uses indicator verbs based on Bloom Taxonomy. In Bloom Revised Taxonomy, higher-orderitems has the knowledge capacity of $\mathrm{C} 4, \mathrm{C} 5$, and C6. While the attitudes of A3 and A4. Then, skills include P3, P4, and P5. Therefore, some students in grade X are associated with PISA result, indicating that students still have not mastered the knowledge, attitude, and skills of higher order context. So that the two predictor variables are closely related to the reading competency of grade $\mathrm{X}$ students who are criterion variables.

There is previous researcher has been conducted study about reading anxiety and reading self-efficacy. Jayoung (2018) conducted a study out relationships among reading anxiety, reading processing, and reading comprehension. Subjects were 265 third-year middle school students in South Korea. The research concluded there were students who have more anxiety use local reading strategies while less anxious students were more focus on completing the reading task and use global reading strategies. Then, reading comprehension of FL reading anxiety in CIG and Global Strategies showed students with less anxious more focus during reading and get higher score. There was negative correlation between reading anxiety and reading processing (Sig. $=-0.20$ ); reading anxiety and reading comprehension $(\mathrm{Sig} .=0.50)$. Then, there was a positive correlation between reading processing and reading comprehension $($ Sig. $=0.60)($ Song, 2018).

Another research was conducted by Ghabdian and Ghafournia in 2016. The research was relationship between Iranian EFL learners' self-efficacy beliefs and reading comprehension ability. The participants consist of 120 students in Neyshabur. The participants' age from 15 until 17 years old. The result of study was a significant relation between self-efficacy and reading comprehension $($ Sig. $=0.69)$. Then, the results of the statistical analysis there was no relation between language learners' self-efficacy belief affected by gender (Ghabdian \& Ghafournia, 2016).

Other empirical evidences support the correlations of the three variables. Lindawati, Tantra, and Ratminingsih (2017) conduct the study about an experimental study on the effect of PARTS strategy and anxiety on reading competency at the eleventhgrade students of SMAN 5 Denpasar. The purpose of the study was to prove the implementation of PARTS Strategy and students' anxiety gave a significant affect to the students' reding competency. The method of the study was an experimental study by applying Post-test only control group design. The research subject was (420 students) nine class of grade XI in academic year 2012/2013. There were 2 classes for samples assign into experimental group and control group. The data collected through questionnaire and analyzed using Statistical Two-Way ANOVA. The result of this study was different effect in reading competency between students that implementing PARTS strategy and who were not by implementing conventional reading strategy ( Sig. $=0.004$ $<\alpha=0.05)$. Then, there was a negative significant relationship between anxiety and students' reading competency (Sig.=0.966) (Lindawati, Tantra, \& Ratminingsih, 2017).

Muhlis in 2017 about foreign language reading anxiety among Indonesian EFL Senior High School. The purpose of the research was to inverstigate foreign language reading anxiety among Indonesian EFL Senior High School. This study was employed a survey research. The research subject was 32 students of grade eleventh in senior high school in Bandung. The data was collected by two questionnaires. The result of this sresearch were three sources of foreign language reading anxiety including unknown vocabulary (49\% students agreed), unfamiliar topic (40\% students agreed), and unfamiliar culture (38\% students agreed). Then, personal factors were making errors 
(39\% students agreed) and worried about reading effect (28\% students agreed) (Muhlis, 2017).

Fitri et.al. (2019) conducted a study about the correlation between reading selfefficacy and reading comprehension. This study applied correlational study which used quantitative design. The study involved 237 of twelfth grade students of science class at SMAN 5 Bengkulu. The data were collected by reading self-efficacy questionnaire and reading comprehension test. The result of this study was a positive significant correlation between reading self-efficacy and reading comprehension. The score of significant level was (Sig. $=0.324)$ (Fitri, Sofyan, \& Jayanti, 2019).

Then, the research was conducted by Morali in 2019. The research was aimed to examine of Turkish foreign language learners' reading self-efficacy in terms of gender, educational level, Turkish language achievement level, and the number of Turkish books read. The research method was descriptive research according to survey model. The study involved 273 international students in high school and university. The one way of variance (ANOVA) analysis, Kruskal-Wallis-H, Mann-Whitney-U and Schefft test to analyze the data. The result of this research was no significant difference in Turkish foreign language learners' reading self-efficacy in terms of gender. But there were significant differences in reading achievement, educational level, language level and number of books read (Morali, 2019)

The fact that scientific approach to reading did not correlate to the students' reading competency, especially in working on high-order thinking items urged the present study to be resurveyed deploying reading anxiety and reading self-efficacy. Moreover, previous researchers had proven two other variables, they are, reading anxiety and reading self-efficacy were proven to be significantly related to reading comprehension of written English texts.

From the result of the previous study, it can be concluded that reading anxiety and reading comprehension, reading self-efficacy and reading comprehension have a significant correlation. Then, reading anxiety, reading self-efficacy have a significant correlation among reading strategy, usage, achievement, and gender in English foreign language learning. However, there was no research conducted above reading anxiety, reading self-efficacy, and reading competency in Vocational High School. Thus, the researcher is interested to conduct the study about multiple relationship among reading anxiety, reading self-efficacy, and reading competency in the EFL context of Vocational High School.

The present research was endeavored to correlate the two predictor variables, namely: reading anxiety, reading self-efficacy, and one criterion variable, that is, reading competency. The reading competency was measured using high-order items, they are, cognitive domain of levels C4, C5, and C6; affective domain of levels A3 and A4; psychomotor domain of levels P3, P4, and P5.

The text genres used were of two types, namely: descriptive texts descriptive text about a person, an animal, a movie, a procedure, and recount texts about a personal experience and an accident. The text indicators measured consisted of four aspects, namely the main idea, the specific ideas, the textual references, and the word meanings. The research was conducted in the State Vocational High Schools in the District of Singaraja, focused especially in the Sekolah Menengah Kejuruan Negeri (SMKN) 1 Sukasada. 


\section{METHOD}

The research population were the tenth-grade students at SMKN 1 Sukasada in the academic year 2019/2020. There were fifteen intact classes in the population with 485 students altogether. There were four classes, one class as a tryout class while three classes as sample class. Tryout class consisted of 30 students. Sample class consisted of 90 students altogether; there are, A class was 30 students, B class was 30 students, and C class was 30 students. This was also done to gain normal sample distribution (Gall, Gall, \& Borg, 2007; Hinkle et al., 1979).

\section{Research Design}

The research design implemented was that of a descriptive and correlational research. Data were analyzed, firstly descriptively, and then, inferentially by implementing a parametric statistics, namely: 1) central tendency measures, 2) measures of dispersion, and 3) ) pair-wise correlations between reading anxiety, reading selfefficacy, and reading competency, and 4) multiple relationships of the predictor variables, they are, reading anxiety and reading self-efficacy, and the criterion variable, that is, reading competency of the eighth grade students at SMKN 1 Sukasada (Gall et al., 2007; Hinkle et al., 1979).

\section{Research Variables}

The current research investigated two combined predictor variables, namely: reading anxiety and reading self-efficacy, and one criterion variable, namely: reading competency (Hinkle et al., 1979).

The first predictor variable was the students' reading anxiety. Reading anxiety was indicated by: 1) communication apprehension, that is, a feeling of anxious when answered wrongly in reading descriptive and recount texts, 2) test anxiety, that is, a feeling of worry when tested in reading descriptive and recount texts, and 3) fear or negative evaluation, that is, a feeling nervous when evaluated negatively in reading descriptive text and recount text (Horwitz, Horwitz, \& Cope, 1986).

The second predictor variable is reading self-efficacy. Reading self-efficacy is a complex construction that can be influenced by the internal factors, namely: 1) mastery experience, 2) vicarious experience, 3) social persuasion, and 4) emotional arousal (Bandura, 1997). According to Bandura (1997), mastery experience is judgement of competence based on evidence or experience that has been experienced previously in class. Vicarious experience is observation of someone achievement in reading activity. Social persuasion is the judgement, feedback, and evaluation from other's about participation in related task. Then, emotional arousal is physical sensation such as anxiety, exhaustion, and calmness that perform in reading activity.

The third variable is a criterion variable, that is, reading competency on the English descriptive and recount texts. Reading competency is a set of attitude, knowledge, and skills (Kurikulum 2013, 2018). According to Latifa (2018) there are four indicators of reading competency, namely: 1) the main idea that is a complete simple sentence which illustrates the general idea of a text, 2) specific ideas are detailed pieces of information containing in the paragraphs, 3) textual references are pronouns in reference to specific nouns in the descriptive and recount texts, and 4) word meanings are the implicational/psychological words/phrases' meanings (Latifa \& Manan, 2018). 


\section{Data Collection Method}

The first instrument used to collect the data was that of a Reading Anxiety Scale. This instrument was a modification of the Foreign Language Reading Anxiety Scale (FLRAS) based on Horwitz's theory (1986). FLARS was meant to measure reading anxiety in general. The modified instrument was directed to the reading indicators, they are, main idea, specific ideas, textual references, and word meanings. According to Horwitz (1986), reading anxiety was indicated 1) communication apprehension describes feeling of anxious when answered wrongly in reading descriptive and recount texts, 2) test anxiety describes feeling of worry when tested in reading descriptive and recount texts, and 3) fear or negative evaluation, describes feeling nervous when evaluated negatively in reading descriptive text and recount text

The second instrument used to collect the data was that of a Reading SelfEfficacy. This instrument was a modification of the Social Learning Theory developed by Bandura (1997). Social Learning Theory was meant to measure reading self-efficacy in general. The modified instrument was directed to the reading indicators, they are, main idea, specific ideas, textual references, and word meanings. According to Bandura (1997), reading self-efficacy was indicated by 1) mastery experience describes feeling of confident in reading descriptive text and recount text, 2) vicarious experience describes experienced feeling in understanding the main idea and specific information in descriptive txt and recount text, 3) social persuasion describes belief in ability to determine the textual references of a descriptive text and recount text, and 4) emotional arousal describes feeling of excitement to determine the word meaning of a descriptive text and recount text.

The third instrument used to collect the data was that of a Reading Competency Test. Reading competency is a set of attitude, knowledge, and skills (Kurikulum 2013, 2018). According to Latifa (2018) there are four indicators of reading competency, namely: 1) the main idea that is a complete simple sentence which illustrates the general idea of a text, 2) specific ideas are detailed pieces of information containing in the paragraphs, 3) textual references are pronouns in reference to specific nouns in the descriptive and recount texts, and 4) word meanings are the implicational/psychological words/phrases' meanings. Aside from the reading indicators, the reading competency test items were designed in higher order cognition, affection, and psychomotor (Latifa \& Manan, 2018).

\section{Instruments' Validation}

Prior to administration, the Reading Anxiety Scale was validated for its content validity and reliability. The instrument was judged independently by two language education experts. The content validity was measured by using Gregory's technique (Candiasa, 2011). The analysis result shows that the two experts agreed as much as $66.66 \%$ or high content validity of the reading anxiety' indicators and descriptors as developed by Horwitz, 1987. The two judges agreed as much as $66.66 \%$ that the reading anxiety's indicators are: 1) communication apprehension, 2) test anxiety, and 3) fear or negative evaluation. Therefore, the Foreign Language Reading Anxiety Scale (FLRAS) could be said as a valid instrument for measuring the students' reading anxiety in SMKN 1 Sukasada.

The Reading Anxiety Scale's reliability coefficient was computed to see the consistency among the reading anxiety indicators, descriptors, and the items developed. To measure the reading anxiety' reliability coefficient, the K-21 was used (Candiasa, 2011). The analysis result shows that the reliability coefficient of the reading anxiety' indicators, descriptors, and the items as developed by Horwitz (1986) was highly reliable 
$=0.857$. Therefore, the Reading Anxiety Scale was a reliable instrument for measuring the students' reading anxiety in SMKN 1 Sukasada.

The Reading Self-Efficacy Scale was validated for its content validity and reliability. The instrument was judged independently by two language education experts. The content validity was measured by using Gregory's technique (Candiasa, 2011). The analysis result shows that the two expert judges agreed as much as $75 \%$ with high content validity of the Reading Self-Efficacy' indicators and descriptors as developed Bandura (1997). Both judges agreed on the content validity of the Reading Self-Efficacy Scale.

The Reading Self-Efficacy Scale's reliability coefficient was computed to see the consistency among the reading anxiety indicators, descriptors, and the items developed. To measure the Reading Self-Efficacy's reliability coefficient, the K-21 was used (Candiasa, 2011). The analysis result shows that the reliability coefficient of the Reading Self-Efficacy's indicators, descriptors, and the items as developed Bandura (1997) was very highly reliable $=0.897$. Therefore, the Reading Self-Efficacy Scale was a reliable instrument for measuring the students' reading self-efficacy in SMKN 1 Sukasada.

The Reading Competency Test was validated for its content validity. The instrument was judged independently by two language education experts. The content validity was measured by using Gregory's technique (Candiasa, 2011). The analysis result shows that the two expert judges agreed as much as $75 \%$ with very high content validity of the reading self-efficacy' indicators and descriptors. Both judges agreed on the content validity of the Reading Competency Test.

The Reading Competency Test's reliability coefficient was computed to see the consistency among the reading anxiety indicators, descriptors, and the items developed. To measure the reading competency test' reliability coefficient, the K-21 was used (Candiasa, 2011).The analysis result shows that the reliability coefficient of the reading competency test's indicators, descriptors, and the items as developed was very highly reliable $=0.836$. Therefore, the Reading Competency Test was a reliable instrument for measuring the students' reading competency in SMKN 1 Sukasada.

\section{Instruments' Trial-Outs}

After the three instruments were validated, they were tried out empirically for readability, reliability, item difficulty, and item discrimination. Readability was meant to check the students' understanding of the statements and/or questions in the Reading Anxiety Scale, the Reading self-Efficacy, and the Reading Competency Test Items. The sample trial-out included 30 students in SMKN 1 Sukasada.

The students' understanding all statements in the Reading Anxiety Scale was measured by asking them the Yes or No to each statement. There scale consisted of 18 items. The students worked independently on the Reading Anxiety Scale for 30 minutes.

The students' understanding all statements in the Reading Self-Efficacy Scale was measured by asking them the Yes or No to each statement. There scale consisted of 24 items. The students worked independently on the Reading Anxiety Scale for 30 minutes.

The students' ability in understanding all questions in the Reading Competency Test was measured by asking them the Yes or No to each item. There test consisted of 25 items. The students worked independently on the Reading Competency for 60 minutes.

The Reading Competency Test's reliability coefficient was computed using the K-21 formula (Candiasa, 2011). The analysis result shows that the reliability coefficient of the Reading Competency was highly reliable $=0.836$. To ensure item difficulty or item facility (IF), the reading competency test was tried out to a sample consisting of 30 students in SMKN 1 Sukasada. The resulting 50 items for testing the students' reading competency are reported in the following table. To compute item difficulty or item facility 
for a criterion-referenced test items, the following formula was used (Candiasa, 2011; Gronlund, 1985). Item discrimination was not computed since the test items were not meant to compare among the students' competency.

\section{Data Analysis Method}

There are two research questions, namely: 1) quantitative descriptions of the two predictor variables- the students' reading anxiety and reading self-efficacy, as well as one criterion variable - the students' reading competency on the English descriptive and recount texts, and 2) inferential analysis in terms of multiple relationships the combined predictor variables and the criterion variable. Therefore, the techniques implemented for the two research questions are as follows.

\section{RESEARCH FINDINGS}

Description of the Students' Reading Interest, Self-Efficacy, and Competency

Table 1 shows the students' reading anxiety averages 43.66 out of the total reading anxiety score $=72.00$. Categorically, the students' reading in high-order-thinking items are high. Their anxious in reading descriptive texts about a person, an animal, a movie, a procedure, and recount texts about a personal experience as well as an accident (in the range scores between 35.92 to 59.14). The students' range score discloses another interesting fact about the students' reading anxiety in SMKN 1 Sukasada. The range between the highest-scored and the lowest-scored students on the reading anxiety scale is close or equal to 29.00. The highest score on reading anxiety is $=49$ and the lowest score on reading anxiety is $=20$. Therefore, the students' reading anxiety variability is large (variance $=60.00$ ).

Table 1. Descriptive Statistics of the Students' Reading Anxiety

\begin{tabular}{|c|l|c|}
\hline No & \multicolumn{1}{|c|}{ Statistics } & Descriptive Values \\
\hline 1 & Arithmetic Mean & 43.66 \\
\hline 2 & Range & 29.00 \\
\hline 3 & Standard Deviation & 7.74 \\
\hline 4 & Variance & 60.00 \\
\hline 5 & Standard Error & 0.81 \\
\hline
\end{tabular}

Source: Data analysis of February 2020, SPSSX version

Table 2 shows the students' reading self-efficacy mean score $=41.10$ out of the total reading self-efficacy score $=96.00$. Categorically, the students' reading self-efficacy in high-order-thinking items are low. Their reading self-efficacy in reading both the descriptive texts about a person, an animal, a movie, a procedure; and recount texts about a personal experience as well as an accident are low (in the range scores between 26.80 to 48.25). The students' range score discloses another interesting fact about the students' reading self-efficacy in SMKN 1 Sukasada. The range between the highest-scored and the lowest-scored students on the reading self-efficacy is equal to 28.00. The students' reading self-efficacy variability is large (variance $=51.21$ ).

Table 2. Descriptive Statistics of the Students' Reading Self-Efficacy

\begin{tabular}{|c|l|r|}
\hline No & \multicolumn{1}{|c|}{ Statistics } & Descriptive Values \\
\hline 1 & Arithmetic Mean & 41.10 \\
\hline 2 & Range & 28.00 \\
\hline 3 & Standard Deviation & 7.15 \\
\hline 4 & Variance & 51.21 \\
\hline 5 & Standard Error & 0.75 \\
\hline
\end{tabular}

Source: Data analysis of February 2020, SPSSX version 
Table 12 shows the students' reading competency mean score $=28.00$ out of the total reading competency score $=100$. Categorically, the students' reading competency in high-order-thinking items are low on both the descriptive texts about a person, an animal, a movie, a procedure, and recount texts about a personal experience as well as an accident (in the range scores between 11.03 to 37.01 ).

The students' range score discloses another interesting fact about the students' reading competency in SMKN 1 Sukasada. The range between the highest-scored and the lowest-scored students on the reading competency is equal to 40.00. Therefore, the students' reading competency variability is very large (variance $=75.01)$.

Table 3. Descriptive Statistics of the Students' Reading Competency

\begin{tabular}{|c|l|r|}
\hline No & \multicolumn{1}{|c|}{ Statistics } & Descriptive Values \\
\hline 1 & Arithmetic Mean & 28.35 \\
\hline 2 & Range & 40.00 \\
\hline 3 & Standard Deviation & 8.70 \\
\hline 4 & Variance & 75.01 \\
\hline 5 & Standard Error & 0.91 \\
\hline
\end{tabular}

Source: Data analysis of February 2020, SPSSX version

\section{Pair-Wise Correlations of Reading Anxiety, Self-Efficacy, and Competency}

Tables 4 show empirical evidences of the relationships among the three variables. Firstly, the students' reading anxiety and their reading self-efficacy in working out highorder-thinking items of both the descriptive and recount texts is negatively and significantly correlated ( $\mathrm{rxy}=-0.77 ; \alpha=0.01$ ). The coefficient index of determination is as much as $59.29 \%$. Put it simply, variance of the students' reading anxiety is shared in common with their reading self-efficacy in working out high-order-thinking items of both the descriptive and recount texts in SMKN 1 Sukasada.

Secondly, the students' reading anxiety and their reading competency in working out high-order-thinking items of both the descriptive and recount texts is negatively and significantly correlated ( $\mathrm{rxy}=-0.77 ; \alpha=0.01$ ). The coefficient index of determination is as much as $59.29 \%$. Put it simply, variance of the students' reading anxiety is shared in common with their reading competency in working out high-order-thinking items of both the descriptive and recount texts in SMKN 1 Sukasada.

Thirdly, the students' reading self-efficacy and their reading competency in working out high-order-thinking items of both the descriptive and recount texts is positively and significantly correlated ( $\mathrm{rxy}=0.75 ; \alpha=0.01$ ). The coefficient index of determination is as much as $56.25 \%$. Put it simply, variance of the students' reading selfefficacy is shared in common with their reading competency in working out high-orderthinking items of the descriptive and recount texts in SMKN 1 Sukasada.

Table 4. Correlation between Reading Anxiety and Self-Efficacy

\begin{tabular}{|l|c|c|c|c|}
\hline & $\begin{array}{c}\text { Reading } \\
\text { Anxiety }\end{array}$ & $\begin{array}{c}\text { Reading } \\
\text { Self- Efficacy }\end{array}$ & $\begin{array}{c}\text { Reading } \\
\text { Competency }\end{array}$ & Significance \\
\hline $\begin{array}{l}\text { Reading } \\
\text { Anxiety }\end{array}$ & 1.00 & -0.77 & -0.77 & 0.01 \\
\hline $\begin{array}{l}\text { Reading } \\
\text { Self- Efficacy }\end{array}$ & -0.77 & 1.00 & 0.75 & 0.01 \\
\hline $\begin{array}{l}\text { Reading } \\
\text { Competency }\end{array}$ & -0.77 & 0.75 & 1.00 & 0.01 \\
\hline
\end{tabular}

Source: Data analysis of February 2020, SPSSX version 


\section{Multiple Correlation of Reading Anxiety, Self-Efficacy, and Competency}

Table 5 shows the simultaneous or multiple relationships of the reading anxiety and reading self-efficacy to the students' reading competency is proven to be significant $\left(R_{y x_{1} x_{2}}=0.81 ; \alpha=0.01\right)$. In other words, when reading become the students' anxiety and their self-efficacy or confidence to read both the descriptive and recount texts, the students' reading competency in finding the main idea, specific ideas, textual reference, and word meanings are negatively, positively and significantly related. In prediction term, the students' reading competency could be accounted for as much as $65.61 \%$ by the students' reading anxiety and reading self-efficacy ( $\mathrm{R}$ square $=0.657$ or Adjusted $\mathrm{R}$ square $=0.649$ ).

Table 5. Multiple Correlation of Reading Anxiety, Self-Efficacy and Competency

\begin{tabular}{|c|c|c|c|c|}
\hline $\mathrm{R}$ & R Square & $\begin{array}{c}\text { Adjusted R } \\
\text { Square }\end{array}$ & $\begin{array}{c}\text { Std. Error of } \\
\text { the Estimate }\end{array}$ & Significance \\
\hline 0.811 & 0.657 & 0.649 & 5.12882 & 0.01 \\
\hline
\end{tabular}

Source: Data analysis of February 2020, SPSSX version

\section{DISCUSSION}

This study was a multiple correlation research focused on the students' reading anxiety, reading self-efficacy, and reading competency on both the descriptive and recount texts in SMKN 1 Sukasada. The research results show three major findings.

First, the students' reading anxiety, reading self-efficacy, and their reading competency on the main ideas, specific ideas, textual references, and word and phrase meanings of both descriptive and recount texts are categorize as at low and high levels. The students' reading anxiety are categorized as at a high level because they were anxious in all the three reading anxiety indicators theorized by Horwitz (1986). The students anxious in determining the main ideas and specific ideas of both descriptive and recount texts. Secondly, they are anxious in understanding the meanings of words and phrases in both the descriptive and recount texts. Thirdly, they are anxious in determining the textual references of both the descriptive and recount texts due to their negative feeling.

The students reading self-efficacy was found at the low level. The students' reading self-efficacy are categorized at a low level because they were not much confident in all the four reading self-efficacy indicators theorized by Bandura (1997). The students' reading self-efficacy is firstly due to their less confident in determining the main ideas of both the descriptive and recount texts. Secondly, the students' reading self-efficacy is due to their lack of experience in determining the specific ideas of both the descriptive and recount texts. Thirdly, the students' reading self-efficacy is due to their less persistent in discovering relevant textual references both in the descriptive and recount texts. Fourthly, the students' reading self-efficacy is due to their not excited in understanding the meanings of words and phrases in both the descriptive and recount texts.

The students' reading competency was measured quantitatively and their reading competency lies at a low level. This level of competency in working on high-order-items on both the descriptive and recount texts could be explained as follows. The students' reading competency is firstly due to their ability in determining the main ideas of both the descriptive and recount texts. Secondly, the students' reading competency is due to their ability in determining the specific ideas of both the descriptive and recount texts. Thirdly, the students' reading competency is thirdly due to their ability in discovering relevant textual references both in the descriptive and recount texts. 
Second, the negative and significant interrelations between reading anxiety and reading self-efficacy, reading anxiety and reading competency, the positive and significant interrelation between reading self-efficacy and reading competency could be speculated as follows. Previous research show that reading anxiety and reading selfefficacy is related negatively because when the students do not have 1) a feeling of confident in determining the main ideas of descriptive and recount texts, 2) an experience in determining the specific ideas of descriptive and recount texts, 3) a feeling of excitement in valuing the textual references in descriptive and recount texts, 4) an ability in understanding the word meanings in descriptive and recount texts, (Bandura, 1997), they will have high anxiety in 1) determining the main ideas and specific ideas of descriptive and recount texts, 2) understanding the word meaning of descriptive and recount texts, and 3) discovering relevant textual references in descriptive and recount texts (Horwitz et al., 1986).

Third, the relations among the two predictor variables (reading anxiety and reading self-efficacy) and the only one criterion variable (reading competency) supports the previous studies. Ghabdian and Ghafournia (2016) conducted a study about relationship between Iranian EFL learners' self-efficacy beliefs and reading comprehension ability. The result study was positive significant relation between selfefficacy and reading comprehension $($ Sig. $=0.69)$. Compared to recent research, the correlation between reading self-efficacy and reading competency is positively and significantly correlated $(\mathrm{Sig} .=0.75)$. This indicates the correlation in new research is higher than previous studies.

Lindawati, Tantra, and Ratminingsih (2017) conduct the study about an experimental study on the effect of PARTS strategy and anxiety on reading competency at the eleventh-grade students of SMAN 5 Denpasar. The result of this study was different effect in reading competency between students that implementing PARTS strategy and who were not by implementing conventional reading strategy (Sig. $=0.004<\alpha=0.05$ ). Then, there was negative significant relationship between anxiety and reading competency (Sig. $=-0.966)$. Compared to recent research, the correlation between reading anxiety and reading competency is negatively and significantly correlated ( $\mathrm{Sig} .=-0.77$ ). This indicates the correlation in new research is lower than previous studies.

Muhlis (2017) conduct the study about foreign language reading anxiety among Indonesian EFL Senior High School. The result of this research were three sources of foreign language reading anxiety including unknown vocabulary (49\% students agreed), unfamiliar topic (40\% students agreed), and unfamiliar culture (38\% students agreed). Then, personal factors were making errors (39\% students agreed) and worried about reading effect ( $28 \%$ students agreed). Compared with recent research, the students have lower level in vocabulary, unfamiliar topic, and high in personality factors such as anxiety. It related with the score of students reading competency is categorically low.

Jayoung (2018) conducted a study out relationship among reading anxiety, reading processing, and reading comprehension. The research concluded there was students who have more anxiety use local reading strategies while less anxious students were more focus on completing the reading task and use global reading strategies. Then, reading comprehension of FL reading anxiety in CIG and Global Strategies showed students with less anxious more focus during reading and get higher scored. There was negative significant relationship between reading anxiety and reading processing ( $\mathrm{Sig} .=$ $0.20)$; reading anxiety and reading comprehension $($ Sig. $=-0.50)$. Then, there was positive significant relationship between reading process and reading comprehension (Sig. $=0.60)$. Compared to recent research, the correlation between reading anxiety and reading 
competency is negatively and significantly correlated $($ Sig. $=-0.77)$. This indicates the correlation in new research is higher than previous studies.

Fitri et.al. (2019) conducted a study about the correlation between reading selfefficacy and reading comprehension. The result of this study was a positive significant correlation between reading self-efficacy and reading comprehension. The score of significant level was 0.324 . Compared to recent research, the correlation between reading self-efficacy and reading competency is positively and significantly correlated (Sig. $=0.75)$. This indicates the correlation in new research is higher than previous studies.

Morali (2019) aimed to examine of Turkish foreign language learners' reading self-efficacy in terms of gender, educational level, Turkish language achievement level, and the number of Turkish books read. The result of this research was no significant difference in Turkish foreign language learners' reading self-efficacy in terms of gender. But there were significant differences in reading achievement, educational level, language level and number of books read. Compared to recent research, students have different abilities, such as the level of self-efficacy in reading. Students' ability can be seen from the result of self-efficacy and reading competency. In new research, students' reading competency is categorically low and self-efficacy categorically low.

\section{CONCLUSION}

The students' reading anxiety on high-order-items on both the descriptive and recount texts in SMKN 1 Sukasada is at the high level, reading self-efficacy, and reading competency on high-order-items on both the descriptive and recount texts in SMKN 1 Sukasada are at the low levels. Then, the relations pair-wisely between the students' reading anxiety and reading self-efficacy, students reading anxiety and reading competency on higher-order-items are negatively and significantly, while the students' reading self-efficacy and reading competency on high-order-items are positively and significantly correlated. The simultaneous or multiple relationships of the reading anxiety and reading self-efficacy to the students' reading competency is proven to be significant.

\section{IMPLICATION}

Firstly, high reading anxiety implies to the students to reduce the anxiety, especially in: (1) determining main ideas, (2) determining the specific ideas, (3) valuing the textual references, (4) understanding the meanings of words and phrases in both the descriptive and recount texts. Secondly, Low reading-efficacy increase the students to be (1) confident in determining the main ideas, (2) having experience in determining the specific ideas, (3) persistent in discovering relevant textual references, and (4) excited in understanding the meanings of words and phrases in both the descriptive and recount texts. Thirdly, low reading competency implies both to the students and EFL teachers to train intensively and extensively in reading processes in order the students have the ability in determining the main ideas, specific ideas, textual references, and word and phrase meanings of both the descriptive and recount texts. Last, Low reading competency implies the headmaster to improve better teaching method is conducted in their schools. This can help increase school performance.

\section{REFERENCES}

Bahmani, R., \& Farvadin, M. T. (2017). Effects of different text difficulty levels on EFL learners' foreign language reading anxiety and reading comprehension. Reading in a Foreign Language, 29(2), 185-202. Retrieved from http://nflrc.hawaii.edu/rf 
Bandura, A. (1997). Self-Efficacy The Exercise of Control. (S. F. Breman, Ed.). New York: W.H. Freeman and Company.

Brown, H. D. (2007). Principles of Language Learning and Teaching Fifth Edition (Fifth Edit). New York: Pearson Education.

Candiasa, I. M. (2011). Pengujian Instrumen Penilaian Disertai Apliksi Iteman dan Bigsteps. Singaraja: Undiksha Press.

Fitri, D. R., Sofyan, D., \& Jayanti, F. G. (2019). The Correlation between Reading SelfEfficacy and Reading Comprehension. Journla of English Education and Teaching, 3(1), 1-13.

Gall, M. D., Gall, J. P., \& Borg, W. R. (2007). Educational research: An introduction (8th ed.). New York: Pearson Education.

Ghabdian, F., \& Ghafournia, N. (2016). The Relationship between Iranian EFL Learners' Self - efficacy Beliefs and Reading Comprehension Ability. English Language Research, 5(1), 38-50. https://doi.org/10.5430/elr.v5n1p38

Gronlund, N. E. (1985). Measurement and Evaluation in Teaching. New York: MacMillan.

Habibian, M., Roslan, S., Idris, K., \& Othman, J. (2015). The Role of Psychological Factors in the Process of Reading. Journal of Education and Practice, 6(29), 114123.

Hinkle, Dennis, Wiersma, William, Jurs, \& Stephen. (1979). Applied Statistics for the Behavioral Sciences. New York: Houghton Milfflin Company.

Horwitz, E. K., Horwitz, M. B., \& Cope, J. (1986). Foreign Language Classroom Anxiety. The Modern Language Journal, O(0), 125-132.

Ikhwan, A. (2018). Management of Learning Assessment Using Curriculum 2013 (Case Study in Islamic Primary School (MI) Muhammadiyah 5 Wonoasri Ponorogo East Java - Indonesia). Managemen of Learning Assessment, 08(02), 108-123.

Kementerian Pendidikan dan Kebudayaan. (2013). Evaluasi Kurikulum 2013 Sudah Tuntas. Retrieved May 29, 2020, from https://www.kemdikbud.go.id/main/blog/2015/12/mendikbud-evaluasikurikulum2013-sudah-tuntas

Kurikulum 2013. (2018). Modul Bahasa dan Sastra Inggris SMA/SMK Kurikulum 2013. Jakarta: Kementerian Pendidikan dan Kebudayaan.

Latifa, N., \& Manan, A. (2018). Teaching Narrative Text by Using Preview, Question, Read, State, And Test (PQRST) Technique. English Education Journal, 2(9), 243 260.

Lindawati, P., Tantra, D. K., \& Ratminingsih, M. (2017). An Experimental Study on The Effect of PARTS Strategy And Anxiety on Reading Competency at The Eleventh Grade Students of SMAN 5 Denpasar. International Journal of Language and Literature, 1(3), 167-174.

Morali, G. (2019). Examination of the Reading Self-Efficacy of Learners of Turkish as a Foreign Language Regarding Some Variables. International Journal of Instruction, 12(1), 1445-1458.

Muhlis, A. (2017). Foreign Language Reading Anxiety. English Franca, 1(1), 19-44. 
Nugrahanto, S., \& Zuchdi, D. (2019). Indonesia PISA Result and Impact on The Reading Learning Program in Indonesia. International Conference on

Interdisciplinary Language, Literature and Education (ICILLE 2018), 297(0), 373-377. Retrieved from http://creativecommons.org/licenses/by-nc/4.0/

PISA. (2012). PISA 2012 Results in Focus, What 15-year-olds know and what they can do with what they know. (OECD, Ed.). OECD.

PISA. (2015). Pisa 2015 Result in Focus. (OECD, Ed.). OECD.

PISA. (2018). PISA 2018 Results. (OECD, Ed.) (OECD, Vol. I, II, III). Retrieved from www.oecd.org/about/publishing/corrigenda.htm

Satthapong, T. (2018). Research and Development of Reading Literacy Follow The PISA Test Using by Reading Apprenticeship Approach. The 2018 International Academic Research Conference in Vienna, 451-456.

Song, J. (2018). Relationships among Reading Anxiety, Reading Processing, and Reading Comprehension Jayoung. Research Gate, 25(2), 83-113. https://doi.org/10.15334/FLE.2018.25.2.83 